\title{
ANTIBACTERIAL EFFECTIVENESS OF 2\% CHITOSAN AND 2\% CHLORHEXIDINE AGAINST ENTEROCOCCUS FAECALIS IN BIOFILM (LABORATORY EXPERIMENT)
}

\author{
PRISCILLA ARLYTA SIMANJUNTAK, NILAKESUMA DJAUHARIE*, BAMBANG NURSASONGKO \\ Department of Conservative Dentistry, Faculty of Dentistry, Universitas Indonesia, Jakarta, 10430, Indonesia. \\ Email: nila.setyopurnomo@gmail.com
}

Received: 27 August 2018, Revised and Accepted: 07 February 2019

\begin{abstract}
Objective: Enterococcus faecalis can form biofilms and has a major role in the etiology of persistent lesions after root canal. We analyzed the efficacy of chitosan and chlorhexidine against $E$. faecalis in biofilms.
\end{abstract}

Methods: Polymerase chain reaction was used to analyze E. faecalis DNA that survived and lived after immersing the biofilm in an antibacterial solution.

Results: A statistically significant difference was noted in living E. faecalis between chitosan and control and between $2 \%$ chlorhexidine and control groups ( $\mathrm{p} \leq 0.05)$. No significant difference was noted between chitosan and chlorhexidine groups $(\mathrm{p}>0.05)$.

Conclusions: Antibacterial effectivity of chitosan is equal to that of chlorhexidine against E. faecalis in biofilm.

Keywords: Chitosan, Chlorhexidine, Enterococcus faecalis, Real-time polymerase chain reaction.

(C) 2019 The Authors. Published by Innovare Academic Sciences Pvt Ltd. This is an open access article under the CC BY license (http://creativecommons. org/licenses/by/4. 0/) DOI: http://dx.doi.org/10.22159/ijap.2019.v11s1.163

\section{INTRODUCTION}

Root canal treatment is divided into three steps known as endodontic triads, which include access preparation, root canal preparation (chemomechanical preparation), and obturation of the root canal space. Root canal treatment aims to eliminate infection in the canal [1]. Such polymicrobial infections are the main cause of periapical lesions. Bacteria infecting the root canal may be either free-floating planktonic forms or biofilms, which are communities of microorganisms linked to each other in an exopolysaccharide matrix. The success of root canal treatment depends primarily on the effectiveness of the elimination of bacterial biofilms in the root canal [2,3].

The most common bacteria that infect the root canal are Gram-negative bacteria with black-pigmented bacteria (BPB, primary endodontic infections) and Enterococcus faecalis (secondary and persistent endodontic infections) [4]. E. faecalis are some high-resistance bacteria that can form biofilms in the root canal, which increases its resistance to various antibacterial agents $[5,6]$. Its high resistance makes E. faecalis the most common bacteria found in cases of endodontic treatment failure (24-77\%) [7].

Root canal preparation using mechanical instruments is an important part in the effort to eliminate root canal bacteria. Kovac and Kovac [8] differentiated the number of bacteria before and after mechanical preparation, without the use of irrigation and medication materials, and found that the number of bacteria in the root canal decreased by $10^{2}-10^{3}$. However, the number of bacteria between visits always increased and reached nearly $50 \%$ of bacterial contamination in root canals after five visits [8]. This was supported by the research of Peters et al. [9], who reported that mechanical preparations with various instrument techniques leave $>35 \%$ of the surface of the untreated root canal, thus failing to completely eliminate root canal bacteria.

This failure is an important reason for the use of antibacterial substances (through irrigation and medication) to eliminate bacteria left in the root canal $[9,10]$. Capik et al. [11] reported that mechanical root canal preparation using irrigation materials with antibacterial effects reduced the amount of bacteria by up to $40-60 \%$. In addition, when a root canal antibacterial drug also was used, the number of bacteria decreased by $90-100 \%$.

Chlorhexidine gluconate is a broad-spectrum antibacterial agent that is active against vegetative and mycobacterial bacteria. Chlorhexidine also is very effective at killing Gram-negative (BPB) and Gram-positive coccus bacteria, including $E$. faecalis. In in vitro studies of E. faecalis on single root canals, Onçağ et al. [12] revealed that, after 5 min of exposure, chlorhexidine $2 \%$ was able to eliminate all $E$. faecalis bacteria. Gomes et al. [13] showed that direct contact with chlorhexidine gel 2\% killed all E. faecalis bacteria.

Chlorhexidine $2 \%$, with high antibacterial power, actually has high toxicity to periapical tissue. Chang et al. [14] measured the fluorescence of propidium iodide (PI) against ligaments of periodontium cell culture and found that chlorhexidine $0.0001 \%$ was toxic to periodontal ligament cells, thus interfering with the healing process. Silva et al. [15] also found that exposure of chlorhexidine $2 \%$ to healthy tissue would trigger an inflammatory response. This led to studies on antibacterial agents with good biocompatibility, such as chitosan.

Chitosan is a natural polysaccharide derived from the exoskeleton of crustaceans and arthropods, and it has an antibacterial effect and low tissue toxicity. Chitosan was discovered in 1859 by Rouget. In 1979, Allan and Hardwiger first studied the antibacterial properties of chitosan, which showed a broad antibacterial spectrum capable of killing Gram-negative and Gram-positive bacteria. Other reports demonstrated the effectiveness of chitosan against Gram-negative and Gram-positive bacteria, including E. faecalis $[16,17]$.

In addition to the high antibacterial effect, chitosan, as a natural ingredient, is safe for consumption. Its use as a food preservative and dietary supplement has been approved by the United States Food and Drug Administration [18]. Shigemasa et al. [19] also demonstrated the ability of chitosan to induce proliferation of fibroblasts and formation 
of granulation tissue with neovascularization, which was essential for healing.

This study analyzed the antibacterial efficacy of chitosan against E. faecalis bacteria in biofilms, with real-time polymerase chain reaction (PCR) to determine its benefit as a safe antibacterial agent in the endodontic field.

\section{METHODS}

This laboratory experimental study was conducted at Bogor Agricultural Institute Laboratory (IPB) from June 2014 to October 2014 . The objective was to analyze the antibacterial efficacy of chitosan $2 \%$ solution and chlorhexidine $2 \%$ solution on E. faecalis bacteria in biofilm by observing the amount of bacteria alive after exposure to the test material.

A chitosan $2 \%$ solution was obtained by mixing 2 g low molecular weight chitosan ( $85 \%$ deacetylation; Sigma-Aldrich Corp., St. Louis, MO, USA) into $100 \mathrm{~mL}$ acetic acid $1 \%$ (vol/vol) up to $2 \%$. The chlorhexidine $2 \%$ solution used in our study was obtained commercially (Consepsis; Ultradent Products, Inc., South Jordan, UT, USA). E. faecalis bacteria American Type Culture Collection (ATCC) 29212 was obtained from KWIK-STIK ${ }^{\mathrm{TM}}$ (Microbiologics, St. Cloud, MN, USA).

E. faecalis ATCC 29212 was applied evenly to the top of Brain Heart Infusion Agar (BHIA) and incubated for $24 \mathrm{~h}$ at $37^{\circ} \mathrm{C}$. The cultured E. faecalis then was obtained using an ose needle and inserted into a reaction tube containing $10 \mathrm{~mL}$ sterile saline. The density of the suspension was standardized with McFarland standard of 0.5 to obtain $10^{8}$ colony-forming units (CFU) $/ \mathrm{mL}$. The cellulose nitrate filter membrane located in the BHIA then was covered with $25 \mu \mathrm{L}$ bacterial suspension and incubated at $37^{\circ} \mathrm{C}$ for $72 \mathrm{~h}$ in aerobic conditions (Fig. 1).

After incubation for $72 \mathrm{~h}$, the sterile membrane was removed aseptically from the BHIA and inserted into an Eppendorf tube with $1 \mathrm{~mL}$ phosphate-buffered saline (PBS) solution to release bacteria that were not firmly attached to the membrane (planktonic bacteria). Then, each membrane was inserted into Eppendorf tubes containing $1 \mathrm{~mL}$ PBS (control), $1 \mathrm{~mL}$ chitosan $2 \%$, and $1 \mathrm{~mL}$ chlorhexidine $2 \%$ solutions (three tubes for each solution) for $10 \mathrm{~min}$ at $37^{\circ} \mathrm{C}$ in an aerobic incubator.

All membranes exposed to the test material as well as the control samples were washed with $1 \mathrm{~mL}$ PBS 3 times to neutralize and stop the activity of the antibacterial agents. Then, the last Eppendorf tube with the membrane was placed on the vortex machine for 2 min to obtain the bacterial suspension, and the membrane then was removed aseptically (Fig. 2)

Propidium monoazide (PMA) was added to the $100 \mu \mathrm{L}$ bacterial suspension until a final concentration of $100 \mu \mathrm{M}$ was obtained. The suspension was incubated for $10 \mathrm{~min}$ at $4^{\circ} \mathrm{C}$ in the dark. Then, the tube was placed on dry ice horizontally and exposed to $600 \mathrm{~W}$ halogen rays for $20 \mathrm{~min}$ at a distance of $20 \mathrm{~cm}$.

A water bath incubator was prepared at $56^{\circ} \mathrm{C}$ and thermal block units at $100^{\circ} \mathrm{C}$. Then, the sample was homogenized for $10 \mathrm{~s}$ and centrifuged at 10,000 revolutions per minute (rpm) for 3 min until dissolved. After centrifugation, the supernatant was discarded, leaving only the natant inside the microcentrifuge tube. Then, the entire natant was combined with $200 \mu \mathrm{L}$ InstaGene ${ }^{\mathrm{TM}}$ Matrix while homogenized over a hot plate using a magnetic stirrer.

The sample then was incubated in a water bath at $56^{\circ} \mathrm{C}$ for $30 \mathrm{~min}$, homogenized for $10 \mathrm{~s}$, and inserted into the thermal block at $100^{\circ} \mathrm{C}$ for $8 \mathrm{~min}$. This procedure was done 3 times.

The sample then was homogenized for $10 \mathrm{~s}$ and centrifuged at $12,000 \mathrm{rpm}$ for $3 \mathrm{~min}$. The supernatant was transferred into a new

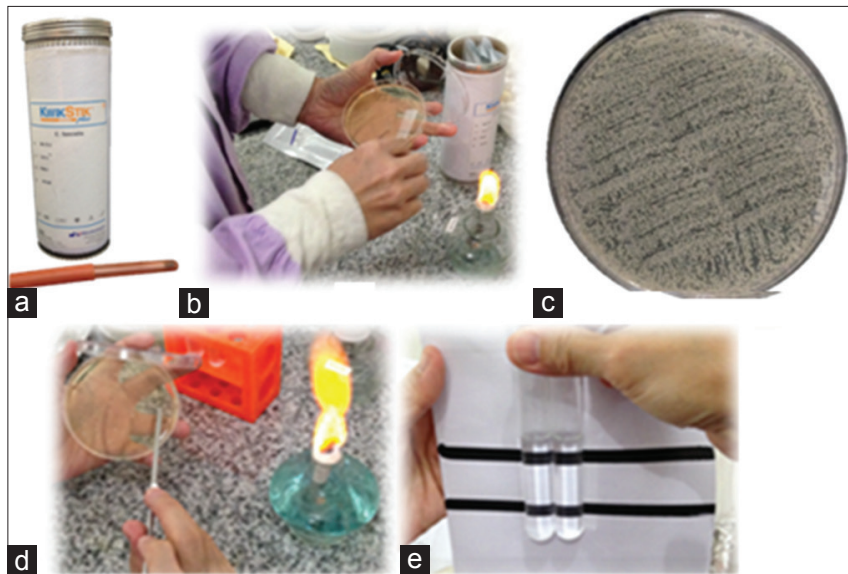

Fig. 1: (a) Enterococcus faecalis American Type Culture Collection (ATCC) $29212^{\mathrm{TM}}$ bacterial preparations. (b) Breeding of $E$. faecalis ATCC $29212^{\mathrm{TM}}$ bacteria in Brain Heart Infusion Agar. (c) Colonies of bacteria formed after incubation for $24 \mathrm{~h}$ at $37^{\circ} \mathrm{C}$. (d) Collecting bacterial colonies using ose needles to be inserted in a reaction tube containing $\mathrm{NaCl}$. (e) Density adjustment in accordance with McFarland standard 0.5

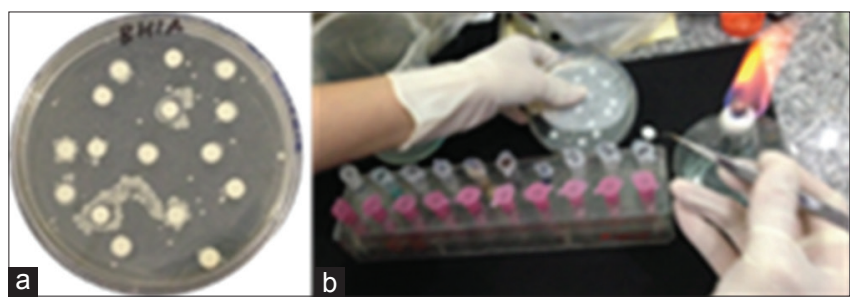

Fig. 2: (a) The biofilm formed after inoculation with Enterococcus faecalis for $72 \mathrm{~h}$ at $37^{\circ} \mathrm{C}$. (b) Washing of biofilm bacteria 3 times with phosphate-buffered saline (PBS) and biofilm exposure to chitosan $2 \%$, chlorhexidine $2 \%$, and PBS (control) for $10 \mathrm{~min}$ at $37^{\circ} \mathrm{C}$

microcentrifuge tube and stored at $4^{\circ} \mathrm{C}$ for $24 \mathrm{~h}$. If natant deposits were still visible, the supernatant was transferred again into a new microcentrifuge tube and stored at $-20^{\circ} \mathrm{C}$.

Primers such as EF Gro ES-F and EF Gro ES-R were diluted using trisethylenediaminetetraacetic (TE) acid buffer with TE buffer ratio: EF Gro ES-F and EF Gro ES-R of 9:1. The diluted sample then was homogenized and spun down. Then, the PCR mix was made in three steps: (1) $1.5 \mathrm{~mL}$ microcentrifuge tubes were coated with aluminum foil. (2) The PCR mix was made by multiplying each mixture by the number of samples to be processed using real-time PCR. The required mixtures consisted of $10 \mu \mathrm{L}$ Power SYBR ${ }^{\circledR}$ Green PCR Master Mix, $2 \mu \mathrm{L}$ universal primers 357F, $2 \mu \mathrm{L}$ universal primers $907 \mathrm{R}$, and $2 \mu \mathrm{L}$ nuclease-free water. (3) All PCR mix materials were mixed into the aluminum foil-coated $1.5 \mathrm{~mL}$ microcentrifuge tubes. Up to $16 \mu \mathrm{L}$ of the prepared mixture was inserted into the MicroAMP ${ }^{\mathrm{TM}}$ fast reaction tubes, $4 \mu \mathrm{L}$ DNA samples were added, and the samples were homogenized using a micropipette.

MicroAmp ${ }^{\mathrm{TM}}$ fast reaction tubes (eight tubes per strip) were covered with the MicroAmp ${ }^{\mathrm{TM}}$ optical 8-Cap strip aseptically. A PCR well plate then was inserted into the step-one real-time PCR system applied biosystem. The real-time PCR quantitative cycle for total bacteria and preheat activation were performed at $95^{\circ} \mathrm{C}$ for $3 \mathrm{~min}$, followed by 40 denaturation cycles at $95^{\circ} \mathrm{C}$ for $15 \mathrm{~s}$, a primary annealing stage at $55^{\circ} \mathrm{C}$ for $30 \mathrm{~s}$, and an elongation stage at $72^{\circ} \mathrm{C}$ for $30 \mathrm{~s}$. After the real-time PCR process was complete, the results were read on the computer screen (Fig. 3). 
Table 1: Mean amount of $E$. faecalis bacteria in biofilm that lived (CFU/mL) after exposure to chitosan $2 \%$ and chlorhexidine $2 \%$

\begin{tabular}{lllll}
\hline Test material & $\mathbf{n}$ & Average \pm SD & \multicolumn{2}{c}{$\mathbf{9 5 \% \text { Confidence Interval }}$} \\
\cline { 3 - 5 } & & & Lower limit & Upper limit \\
\hline Chitosan 2\% & 3 & $2.953 \times 10^{3} \pm 3.008 \times 10^{3}$ & $-4.519 \times 10^{3}$ & $1.043 \times 10^{4}$ \\
Chlorhexidine 2\% & 3 & $8.355 \times 10^{3} \pm 1.287 \times 10^{4}$ & $-2.361 \times 10^{4}$ & $4.032 \times 10^{4}$ \\
Control & 3 & $1.66 \times 10^{8} \pm 4.036 \times 10^{7}$ & $6.574 \times 10^{7}$ & $2.663 \times 10^{8}$ \\
\hline
\end{tabular}

E. faecalis: Enterococcus faecalis, SD: Standard deviation, CFU: Colony-forming unit

Table 2: Mean E. faecalis amount between treatment groups

\begin{tabular}{llll}
\hline Test material & Chitosan 2\% & Chlorhexidine 2\% & Control \\
\hline Chitosan 2\% & - & 0.827 & $0.05^{*}$ \\
Chlorhexidine 2\% & 0.82700 & - & $0.05^{*}$ \\
Control & $0.05^{*}$ & $0.05^{*}$ & - \\
\hline
\end{tabular}

Post hoc Mann-Whitney U-test, $\mathrm{p} \leq 0.05$. E. faecalis: Enterococcus faecalis

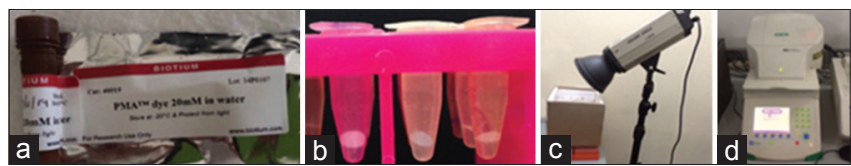

Fig. 3: ( $a$ and b) Addition of propidium monoazide and incubation in the dark. (c) Exposure with $600 \mathrm{~W}$ for $20 \mathrm{~min}$. (d) Detection and quantification of DNA Enterococcus faecalis through real-time polymerase chain reaction

We determined the number of $E$. faecalis bacteria that lived after biofilm exposure to chitosan antibacterial $2 \%$ and chlorhexidine $2 \%$ for $10 \mathrm{~min}$, in absolute quantification form. The obtained data then were analyzed using SPSS 20.0 program.

Data were analyzed statistically. The number of surviving E. faecalis bacteria from the control and material groups was first analyzed for normality and homogeneity. If the distribution data were normal and homogeneous, then the test continued using one-way analysis of variance. If the difference was significant, a multiple comparison test with post hoc least significant difference was performed. If the data distribution was not normal or homogeneous, a non-parametric test, such as the KruskalWallis and post hoc Mann-Whitney $U$-tests, was performed.

\section{RESULT}

The distribution of data on the number of bacteria was not homogenous, so the non-parametric Kruskal-Wallis test was used to assess the significance of the bacterial yield number.

The lowest and highest $E$. faecalis amounts were found in the chitosan (average, 2.953×103 $\mathrm{CFU} / \mathrm{mL}$ ) and control (average, $1.66 \times 108$ $\mathrm{CFU} / \mathrm{mL}$ ) groups, respectively (Table 1 ).

There was a significant difference in bacterial amount between the control and chitosan $2 \%$ groups $(\mathrm{p} \leq 0.05$ and $\mathrm{p}=0.05$ ) and also between the control and chlorhexidine $2 \%$ groups $(\mathrm{p} \leq 0.05$ and $\mathrm{p}=0.05$; Table 2$)$. However, there was no significant difference between the chitosan $2 \%$ and chlorhexidine $2 \%$ groups ( $p>0.05$ and $p=0.827$ ).

\section{DISCUSSION}

This study analyzed the antibacterial efficacy of chitosan on E. faecalis biofilm. E.faecalis is commonly found in endodontic treatment failure and it is highly resistant to various antibacterial agents because it can form biofilm in root canal.

A study of biofilm resistance relationship by the age of the biofilm suggests that mature biofilms are more difficult to destroy than younger biofilms. Santos et al. [23] stated that extracellular polysaccharides (EPS) from biofilms appear to be distributed evenly on the $3^{\text {rd }}$ day, whereas in the first $24 \mathrm{~h}$, no or only a few EPS are found on biofilms. Stoodley et al. [24] also investigated the growth of biofilms microscopically and found that $E$. faecalis biofilms began to mature and stabilize.

The biofilms in our study formed on a cellulose nitrate membrane as was used by some investigators to examine antibacterial efficacy of a substance against E. faecalis biofilm. Chai et al. [25] stated that this method allows for the growth of biofilms on standardized surfaces, thus providing a more accurate assessment of the efficacy of an antibacterial material.

We used pure strain ATCC 29212 E. faecalis bacteria, which is a standard bacteria that have been used widely in many studies. ATCC is an international standard choice because it has complete characteristics in each strain. In addition, ATCC uses a seed stock system to minimize subculture methods and has good protective and storage protocols to maintain the safety and effectiveness of culture [26].

Chlorhexidine is widely used to kill E. faecalis in the endodontic field. It is a broad-spectrum antimicrobial active against Gram-positive, Gramnegative, and fungal bacteria. Studies on the antibacterial efficacy of various chlorhexidine concentrations against $E$. faecalis that were inoculated into root canals reported that chlorhexidine $2 \%$ provided the best antibacterial power $[27,28]$. On the basis of these results, we used chlorhexidine $2 \%$ as a positive control in our study.

With increasing treatment using natural ingredients, chitosan became a preferred ingredient that is widely used in the medical world. On the basis of several studies, chitosan is believed to have antimicrobial power and is not toxic to tissue $[18,29]$.

Two main factors that affect the antibacterial power of chitosan are the molecular weight and degrees of chitosan deacetylation (DD). We used low molecular weight chitosan (87.875 Da) with an $84 \%$ DD. The smaller the weight of the chitosan molecule, the greater its ability to inhibit growth and multiplication of microorganisms [30]. This was in accordance with the results of a study by Liu et al., who showed that low molecular weight chitosan had the highest antibacterial power against Escherichia coli bacteria [31]. Thus, the use of low molecular weight chitosan allows for easier mobility and ion interaction, thereby enhancing effective bonding with bacterial membrane surfaces [16].

The DD, the percentage of units (glucosamine monomer) that is deacetylated in the chitosan chain affects the chemical, physical, and biological properties of chitosan, such as the strain strength of a film, ability to clamp metal ions, and immunoadjuvant activity. DD also affects the intrinsic pKa of chitosan, thus affecting the solubility of chitosan in acid. For chitosan to dissolve in acid, its DD must be $\geq 40 \%$ [29]. DD affects the amount of positive charge of chitosan. The higher the DD, the higher the positive charge and the better the antibacterial power [31]. The high DD (84\%) in our study aimed to obtain acid-soluble chitosan with high antibacterial power.

In our study, antibacterial power was analyzed using real-time PCR with PMA staining. Real-time PCR has higher sensitivity and higher accuracy than the culture method and also can provide more detailed and accurate quantitative results [32]. Venieri et al. [33] compared the value of post-exposure bacterial number using real-time PCR and culture 
methods and found that real-time PCR provided more detailed and accurate results. This is because PCR can detect viable but non-cultivable (VBNC) bacteria, as shown by E. faecalis, whereas conventional culture methods are only capable of culturing live bacterial cells that can form colonies on nutrient media, without detecting dead cells, VBNC cells, or bacteria requiring special conditions to grow $[33,34]$.

One disadvantage of real-time PCR is that it detects all DNA (living and dead). This can be solved by a widely used intercalation material in real-time PCR to discriminate and count the number of living and dead cells in a microbiological sample. This method uses PMA, a derivative of PI that is widely used in microscopic cytometry to dye dead cells. PMA penetrates into the damaged cell membrane and binds the DNA of the cell, so it cannot be amplified in the real-time PCR process [34]. With the use of PMA in our study, the number of living bacterial DNA in the test material and control groups could be detected.

Chlorhexidine $2 \%$ is widely used in the endodontic field due to its effectiveness at killing $E$. faecalis. Kim etal. [35] examined the effectiveness of chlorhexidine against $E$. faecalis biofilm, resulting from inoculation in the root canal. The results showed that chlorhexidine $2 \%$ effectively killed E. faecalis bacteria in biofilm and its effectiveness continued to increase from 5 to 10 min after exposure [35]. This previous study supports our results, showing a $99 \%$ difference in E. faecalis amount between the control (untreated) and $2 \%$ chlorhexidine test groups.

Like chlorhexidine $2 \%$, chitosan $2 \%$ also has antibacterial power against $E$. faecalis, as proven by our results and those of Ballal et al. [36] However, few studies exist on the effects of chitosan on E. faecalis biofilm.

In our study, chitosan $2 \%$ had similar antibacterial power against E. faecalis biofilm as chlorhexidine $2 \%$. This is supported by Verkaik et al. [37], who reported that chlorhexidine and chitosan have good effectiveness against Streptococcus oralis biofilms, Gram-positive coccus bacteria. The antibacterial power of both materials is due to their ability to stick to the surface of the biofilm and release their antibacterial effects [37].

The antibacterial effectiveness of chitosan and chlorhexidine may be due to the similar working mechanisms of both materials. Chlorhexidine and chitosan are antimicrobial cations that act on the cell membrane, thereby increasing permeability and facilitating the release of intracytoplasmic material. The positive ions of chlorhexidine and chitosan attach to negative ions from the outer surface of biofilms and cell membranes that cause hydrolysis of the peptidoglycan on the bacterial wall, resulting in intracellular electrolyte leakage (e.g., nucleic acid and glucose). This leads to the death of bacterial cells $[16,38]$.

In addition to the above mechanism, chitosan is believed to be a sailor agent, which is capable of binding to metal ions. Darrag [39] examined the effect of chitosan $0.2 \%$ on screen smears in root canals and found that chitosan is a sailor agent capable of lifting the smear layer from within the root canal of dentin tubule. This is because chitosan has a hydrophilic nature, thus allowing good contact with the dentin wall of the root canal. In addition, the hydroxyl ions and cationic properties of chitosan enable it to be a sailor agent that has a role in the exchange of dentine ions and minerals. Furthermore, acetic acid becomes a solvent, which increases the sailing effect of chitosan [39].

Abdel-Aziz [40] described the various mechanisms of an antibody agent, one of which is by a sailing mechanism. Metallic ions, such as calcium, magnesium, and iron, have a role in maintaining the integrity of the biofilm matrix. The sailor agent is able to disrupt the stability of the biofilm structure and bacterial membrane [40]. This may be a contributing factor in the antibiofilm mechanism of chitosan. However, further research is needed to determine the mechanism of action of chitosan on biofilms.
Our results are different from those of Ballal et al. [36], who stated that chlorhexidine $2 \%$ is more effective than chitosan $2 \%$. This can be due to the different research methods. Ballal et al. [36] used an agar diffusion method, whereas we assessed antibacterial efficacy using the direct contact method. With the agar diffusion technique, the diffusion ability of these two materials can affect their antibacterial efficacy. In addition, Ballal et al. [36] used planktonic bacteria, whereas we used biofilms.

\section{CONCLUSIONS}

Chitosan $2 \%$ had antibacterial power against E. faecalis in biofilm. The antibacterial efficacy of chitosan $2 \%$ was proportional to the antibacterial efficacy of chlorhexidine $2 \%$ in killing $E$. faecalis bacteria in biofilms.

\section{CONFLICTS OF INTEREST}

The author report no conflicts of interest.

\section{REFERENCES}

1. Beer R, Baumann MA, Kim S. Disinfection. In: Rateitschak KH, Wolf HF, editors. Color Atlas of Dental Medicine: Endodontology. Stuttgart: Thieme; 2000. p. 145-64.

2. Narayanan LL, Vaishnavi C. Endodontic microbiology. J Conserv Dent 2010;13:233-9.

3. Shrestha A, Shi Z, Neoh KG, Kishen A. Nanoparticulates for antibiofilm treatment and effect of aging on its antibacterial activity. J Endod 2010;36:1030-5

4. Siqueira JF, Rocas IN. Update on Endodontic Microbiology: Candidate Pathogens and Patterns of Colonisation. Vol. 2. England: ENDO; 2008. p. 7-20.

5. Williamson AE, Cardon JW, Drake DR. Antimicrobial susceptibility of monoculture biofilms of a clinical isolate of Enterococcus faecalis. J Endod 2009;35:95-7.

6. Retamozo B, Shabahang S, Johnson N, Aprecio RM, Torabinejad M. Minimum contact time and concentration of sodium hypochlorite required to eliminate Enterococcus faecalis. J Endod 2010;36:520-3.

7. Stuart CH, Schwartz SA, Beeson TJ, Owatz CB. Enterococcus faecalis: Its role in root canal treatment failure and current concepts in retreatment. J Endod 2006;32:93-8.

8. Kovac J, Kovac D. Effect of irrigating solutions in endodontic therapy. Bratisl Lek Listy 2011;112:410-5.

9. Peters OA, Schönenberger K, Laib A. Effects of four ni-ti preparation techniques on root canal geometry assessed by micro computed tomography. Int Endod J 2001;34:221-30.

10. Baugh D, Wallace J. The role of apical instrumentation in root canal treatment: A review of the literature. J Endod 2005;31:333-40.

11. Capik I, Sevchikova Z, Ledecky V. Radiological and histological assessment of periapical repair afetr obturation of infected root canals in dogs. Acta Vet Brno 2005;74:237-42.

12. Onçağ $\mathrm{O}$, Hoşgör M, Hilmioğlu S, Zekioğlu O, Eronat C, Burhanoğlu D, et al. Comparison of antibacterial and toxic effects of various root canal irrigants. Int Endod J 2003;36:423-32.

13. Gomes BP, Souza SF, Ferraz CC, Teixeira FB, Zaia AA, Valdrighi L, et al. Effectiveness of $2 \%$ chlorhexidine gel and calcium hydroxide against Enterococcus faecalis in bovine root dentine in vitro. Int Endod J 2003;36:267-75

14. Chang YC, Huang FM, Tai KW, Chou MY. The effect of sodium hypochlorite and chlorhexidine on cultured human periodontal ligament cells. Oral Surg Oral Med Oral Pathol Oral Radiol Endod 2001; 92:446-50

15. Silva RA, Assed S, Nelson-Filho P, Silva LA, Consolaro A. Subcutaneous tissue response of isogenic mice to calcium hydroxidebased pastes with chlorhexidine. Braz Dent J 2009;20:99-106.

16. Goy RC, Britto DD, Assis OB. A review of the antimicrobial activity of chitosan. Polím Ciência Tecnol 2009;19:241-7.

17. Chitosan AA. In: Alishahi A, editor. A Bioactive Polysaccharide in Marine-Based Foods. London. IntechOpen; 2012. p. 409-28.

18. Struszcyzk MH. Chitin and chitosan: Part II. Applications of chitosan. Polimery 2002:47:396-401.

19. Shigemasa Y, Minami S. Applications of Chitin and Chitosan for Biomaterials. Biotechnology and Genetic Engineering Reviews 1995; 13:383-419.

20. Hunt M. Real Time PCR; 2010. Available from: http://www.pathmicro. med.sc.edu/pcr/realtime-home.htm. 
21. Suchitrau S, Kundabala K. Enterococus faecalis: An endodontic pathogen. Endodontology 2006;18:11-3.

22. Mathew S. Enterococcus faecalis an endodontic challenge. JIADS 2010;12:33-7.

23. Santos RP, Arruda TT, Carvalho CB, Carneiro VA, Braga LQ, Teixeira EH, et al. Correlation between Enterococcus faecalis biofilms development stage and quantitative surface roughness using atomic force microscopy. Microsc Microanal 2008;14:150-8.

24. Stoodley P, Sidhu S, Nistico L, Mather M, Boucek A, Hall-Stoodley L, et al. Kinetics and morphology of polymicrobial biofilm formation on polypropylene mesh. FEMS Immunol Med Microbiol 2012;65:283-90.

25. Chai WL, Hamimah H, Cheng SC, Sallam AA, Abdullah M. Susceptibility of Enterococcus faecalis biofilm to antibiotics and calcium hydroxide. J Oral Sci 2007;49:161-6.

26. Wang QQ, Zhang CF, Chu CH, Zhu XF. Prevalence of Enterococcus faecalis in saliva and filled root canals of teeth associated with apical periodontitis. Int J Oral Sci 2012;4:19-23.

27. Mohammadi Z, Abbott PV. The properties and applications of chlorhexidine in endodontics. Int Endod J 2009;42:288-302.

28. Vianna ME, Gomes BP, Berber VB, Zaia AA, Ferraz CC, de SouzaFilho FJ, et al. In vitro evaluation of the antimicrobial activity of chlorhexidine and sodium hypochlorite. Oral Surg Oral Med Oral Pathol Oral Radiol Endod 2004;97:79-84.

29. Abbas AO. Chitosan for Biomedical Applications PhD (Doctor of Philosophy) Thesis. USA: University of Iowa; 2010.

30. Liu N, Chen XG, Park HJ. Effect of MW and concentration of chitosan on antibacterial activity of Escherichia coli. Sci Direct 2006;64:60-5.

31. Kong M, Chen XG, Xing K, Park HJ. Antimicrobial properties of chitosan and mode of action: A state of the art review. Int J Food Microbiol 2010;144:51-63.

32. Hedge V. Enterococcus faecalis; clinical significance and treatment considerations. Endodontology. 2009;21:48-52.

33. Venieri D, Chatzisymeon E, Gonzalo MS, Rosal R, Mantzavinos D. Inactivation of Enterococcus faecalis by $\mathrm{TiO} 2-$ mediated UV and solar irradiation in water and wastewater: Culture techniques never say the whole truth. Photochem Photobiol Sci 2011;10:1744-50.

34. Alvarez G, González M, Isabal S, Blanc V, León R. Method to quantify live and dead cells in multi-species oral biofilm by real-time PCR with propidium monoazide. AMB Express 2013;3:1.

35. Kim HS, Woo Chang S, Baek SH, Han SH, Lee Y, Zhu Q, et al. Antimicrobial effect of alexidine and chlorhexidine against Enterococcus faecalis infection. Int J Oral Sci 2013;5:26-31.

36. Ballal N, Kundabala M, Bhat K, Acharya S, Ballal M, Kumar R, et al. Susceptibility of Candida albicans and Enterococcus faecalis to chitosan, chlorhexidine gluconate and their combination in vitro. Aust Endod J 2009;35:29-33.

37. Verkaik MJ, Busscher HJ, Jager D, Slomp AM, Abbas F, van der Mei HC, et al. Efficacy of natural antimicrobials in toothpaste formulations against oral biofilms in vitro. J Dent 2011;39:218-24.

38. Kandaswamy D, Venkateshbabu N. Root canal irrigants. J Conserv Dent 2010;13:256-64.

39. Darrag AM. Effectiveness of different final irrigation solutions on smear layer removal in intraradicular dentin. Tanta Dent J 2014;11:93-99.

40. Abdel-Aziz SM, Aeron A. Bacterial biofilm: Dispersal and inhibition strategies. SAJ Biotechnol 2014;1:105-14. 